\title{
Image Documentation in Gastrointestinal Endoscopy: Review of Recommendations
}

\author{
Susana Marques ${ }^{a}$ Miguel Bispo ${ }^{a}$ Pedro Pimentel-Nunes ${ }^{b}$ Cristina Chagas ${ }^{a}$ \\ Mário Dinis-Ribeiro ${ }^{b}$ \\ a Department of Gastroenterology, Hospital de Egas Moniz, Centro Hospitalar Lisboa Ocidental, Lisbon, and

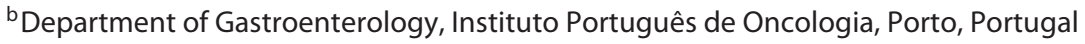

Keywords

Endoscopy $\cdot$ Gastrointestinal tract $\cdot$ Recommendations

\section{Abstract}

In recent years, endoscopic image documentation has gained an important role in gastrointestinal (GI) endoscopic reporting and has become an integral aspect of quality control. Since 2001, several important guidelines and statements, some from major endoscopic societies, have been published to standardize endoscopic image documentation. Therefore, and according to the most recent recommendations of the European Society of Gastrointestinal Endoscopy, we propose a set of images to be routinely captured in upper and lower Gl endoscopy. Systematic acquisition of 10 and 9 photographs of specific landmarks is recommended in upper-Gl endoscopy and colonoscopy, respectively. In addition to photo documentation of the normal endoscopic features, imaging of pathologic findings is also advocated. Considering accurate and adequate image documentation as an essential part of endoscopic reporting, it should be systematically performed in upper and lower GI endoscopy.

(c) 2017 Sociedade Portuguesa de Gastrenterologia Published by S. Karger AG, Basel

\section{Iconografia em Endoscopia Gastrointestinal: Revisão de Recomendações}

\section{Palavras Chave}

Endoscopia $\cdot$ Tracto gastrointestinal $\cdot$ Recomendações

\section{Resumo}

Nos últimos anos, a documentação por imagem tem adquirido um papel preponderante na elaboração do relatório em endoscopia digestiva, tornando-se num importante parâmetro no controlo de qualidade.

Desde 2001, várias recomendações e vários comunicados, alguns de sociedades endoscópicas de relevo, têm sido publicados com o intuito de estandardizar a documentação por imagem em endoscopia. Por conseguinte, e de acordo com as mais recentes recomendações da European Society of Gastrointestinal Endoscopy, propomos um conjunto de imagens a serem capturadas por rotina em endoscopia digestiva alta e baixa. A aquisição sistemática de dez e de nove fotografias de locais de referência específicos é sugerida na endoscopia digestiva alta e na colonoscopia, respectivamente. Além da fotodocumen-

\begin{tabular}{ll}
\hline KARGER & $\begin{array}{l}\text { (c) } 2017 \text { Sociedade Portuguesa de Gastrenterologia } \\
\text { Published by S. Karger AG, Basel Karger }\end{array}$ \\
E-Mail karger@karger.com & \\
www.karger.com/pjg & This article is licensed under the Creative Commons Attribution- \\
& $\begin{array}{l}\text { NonCommercial-NoDerivatives 4.0 International License (CC BY- } \\
\text { NC-ND) (http://www.karger.com/Services/OpenAccessLicense). } \\
\text { Usage and distribution for commercial purposes as well as any dis- } \\
\text { tribution of modified material requires written permission. }\end{array}$
\end{tabular}

Dr. Susana Marques

Department of Gastroenterology, Hospital de Egas Moniz Centro Hospitalar Lisboa Ocidental, Rua da Junqueira 126 PT-1349-019 Lisbon (Portugal)

E-Mail xsusanamarx@gmail.com 
tação de aspectos endoscópicos normais, é recomendada a obtenção de imagens de achados patológicos.

Sendo considerada uma parte essencial do relatório em endoscopia, a adequada e rigorosa documentação por imagem, esta deve ser realizada de forma sistemática em endoscopia digestiva alta e baixa.

(C) 2017 Sociedade Portuguesa de Gastrenterologia Publicado por S. Karger AG, Basel

\section{Introduction}

With the spread of affordable digital imaging systems, endoscopic image documentation has become widely available and has gained a major role in endoscopic reporting. Adequate, relevant, and quality image documentation is necessary to faithfully document endoscopic findings and interventions. Furthermore, it is the best method of ascertaining the completeness of an endoscopic procedure [1]. Consequently, photo documentation has become an integral aspect of endoscopic quality control.

\section{Past and Present}

In recent years, there has been an increasing demand for proper photo documentation of endoscopic procedures (Tables 1, 2). In 2001, the European Society of Gastrointestinal Endoscopy (ESGE) presented the first guidelines for standardized image documentation in upper and lower gastrointestinal (GI) endoscopy [1]. In both examinations, these guidelines recommend the acquisition of 8 images of particular GI landmarks. In case of pathologic findings, complementary images should also be taken. In upper GI endoscopy, 2 esophageal, 4 gastric, and 2 duodenal standard images are proposed. In colonoscopy, 7 colonic and 1 rectal images are recommended. These pictures should be numbered from 1 to 8 , with the highest number corresponding to the most distant sector reached.

In 2008, representatives from the American Society of Gastrointestinal Endoscopy (ASGE), the American Society of Gastroenterology (AGA), the American College of Gastroenterology (ACG), and the American Medical Association (AMA) developed the "Endoscopy and Polyp

Table 1. Recommended images of landmarks in upper GI endoscopy

\begin{tabular}{|c|c|c|c|}
\hline Recommendations & Esophagus & Stomach & Duodenum \\
\hline ESGE [1] (2001) & $\begin{array}{l}\text { Proximal esophagus (taken } \\
20 \mathrm{~cm} \text { from the incisor) } \\
\text { Z-line (taken } 2 \mathrm{~cm} \text { above) }\end{array}$ & $\begin{array}{l}\text { Cardia and fundus on retroflexed view } \\
\text { Body (taken from the upper part of the lesser } \\
\text { curvature) } \\
\text { Angulus on partial retroflexion } \\
\text { Antrum }\end{array}$ & $\begin{array}{l}\text { Duodenal bulb } \\
\text { 2nd part of the duodenum (taken near the } \\
\text { ampulla) }\end{array}$ \\
\hline $\begin{array}{l}\text { WCOG } 2013 \text { Working } \\
\text { Party Report [5] (2014) }\end{array}$ & $\begin{array}{l}\text { Z-line and gastroesophageal } \\
\text { junction }\end{array}$ & $\begin{array}{l}\text { Cardia and fundus on retroflexed view } \\
\text { Body } \\
\text { Angulus } \\
\text { Antrum }\end{array}$ & $\begin{array}{l}\text { Distal extend of examination in the } \\
\text { duodenum }\end{array}$ \\
\hline $\begin{array}{l}\text { ASGE/ACG/AGA }[6,7] \\
(2015)\end{array}$ & Not defined* & Not defined* & Not defined* \\
\hline Tang et al. [9] (2015) & $\begin{array}{l}\text { Esophageal introitus } \\
\text { Proximal, middle, and distal } \\
\text { esophagus } \\
\text { Gastroesophageal junction }\end{array}$ & $\begin{array}{l}\text { Cardia and fundus on retroflexed view } \\
\text { Body on either forward and retroflexed view } \\
\text { Angulus on retroflexed view } \\
\text { Antrum and pyloris }\end{array}$ & $\begin{array}{l}\text { Duodenal bulb } \\
\text { 2nd or 3rd portion of the duodenum } \\
\text { Ampulla (optional) }\end{array}$ \\
\hline ESGE [4] (2016) & $\begin{array}{l}\text { Proximal esophagus } \\
\text { Distal esophagus } \\
\text { Z-line and diaphragm } \\
\text { indentation }\end{array}$ & $\begin{array}{l}\text { Cardia and fundus on retroflexed view } \\
\text { Body on either forward (including } \\
\text { lesser curvature) or retroflexed } \\
\text { view (including greater curvature) } \\
\text { Angulus on partial retroflexion } \\
\text { Antrum }\end{array}$ & $\begin{array}{l}\text { Duodenal bulb } \\
\text { 2nd part of the duodenum, including the } \\
\text { ampulla }\end{array}$ \\
\hline
\end{tabular}

* Photodocumentation of important anatomic landmarks is recommended, but these are not specified. 
Surveillance - Physician Performance Measurement Set" [2]. For the first time, photo documentation was included as an integral aspect of endoscopic quality control. Photo imaging of cecal landmarks, including the appendiceal orifice and ileocecal valve, was incorporated as a quality measure in colonoscopy.

Later, in 2012, the ESGE released "Quality in screening colonoscopy: position statement of the ESGE" [3]. In addition to the set of 8 standard images in colonoscopy previously recommended by the ESGE in 2001, a ninth photograph (forward view of the rectum) is suggested. Just recently, in 2016, the ESGE has published "Performance measures for upper GI endoscopy: a ESGE quality improvement initiative" [4]. These recommendations advo- cate the acquisition of 10 images of specific landmarks of the upper GI tract (2 more photographs: 1 esophageal and 1 gastric).

Because ESGE guidelines were not widely implemented, The World Congress of Gastroenterology (WCOG) 2013 Working Party Report suggested a simplified standard that would offer the same utility, possibly increasing the acceptance [5]. In this report, only 4 images were advocated for upper GI endoscopy and a minimum of 2 for colonoscopy.

A few years later, in 2015, the ASGE released the second and latest version of "Quality indicators in GI endoscopic procedures," endorsed by the AGA and the ACG [6-8]. In upper GI endoscopy, photo documentation of

Table 2. Recommended images of landmarks in colonoscopy

\begin{tabular}{|c|c|c|c|c|}
\hline Recommendations & Terminal ileum & Colon & Rectum & Anal canal perianal area \\
\hline ESGE [1] (2001) & - & $\begin{array}{l}\text { Cecum and appendiceal orifice } \\
\text { Ileocecal valve } \\
\text { Ascending colon under the hepatic flexure } \\
\text { Transverse colon just distal to the hepatic } \\
\text { flexure } \\
\text { Transverse colon just proximal to the splenic } \\
\text { flexure } \\
\text { Descending colon below the splenic flexure } \\
\text { Middle part of the sigmoid }\end{array}$ & $\begin{array}{l}\text { Lower part of the } \\
\text { rectum (taken } 2 \mathrm{~cm} \\
\text { above the anal line) }\end{array}$ & - \\
\hline $\begin{array}{l}\text { ASGE/ACG/AGA/AMA [2] } \\
(2008)\end{array}$ & - & Cecum, appendiceal orifice, and ileocecal valve & - & - \\
\hline ESGE [3] (2012) & $\begin{array}{l}\text { Optional } \\
\text { (if intubated) }\end{array}$ & $\begin{array}{l}\text { Cecum and appendiceal orifice (taken from a } \\
\text { distance of } 2-4 \mathrm{~cm} \text { to encompass the cecal strap } \\
\text { fold) } \\
\text { Cecum and ileocecal valve } \\
\text { Ascending colon under the hepatic flexure } \\
\text { Transverse colon just distal to the hepatic } \\
\text { flexure } \\
\text { Transverse colon just proximal to the splenic } \\
\text { flexure } \\
\text { Descending colon below the splenic flexure } \\
\text { Middle part of the sigmoid* }\end{array}$ & $\begin{array}{l}\text { Lower part of the } \\
\text { rectum in both } \\
\text { forward (taken } 2 \mathrm{~cm} \\
\text { above the anal line) } \\
\text { and retroflexed } \\
\text { views }\end{array}$ & - \\
\hline $\begin{array}{l}\text { WCOG } 2013 \text { Working Party } \\
\text { Report [5] (2014) }\end{array}$ & $\begin{array}{l}\text { Optional } \\
\text { (in alternative to } \\
\text { cecal landmarks) }\end{array}$ & $\begin{array}{l}\text { Cecum and appendiceal orifice } \\
\text { Ileocecal valve } \\
\text { The least cleansed of the three colonic segments }\end{array}$ & $\begin{array}{l}\text { Optional } \\
\text { (retroflexed view if } \\
\text { performed) }\end{array}$ & - \\
\hline $\begin{array}{l}\text { ASGE/ACG/ AGA }[6,8] \\
(2015)\end{array}$ & $\begin{array}{l}\text { Optional } \\
\text { (in alternative to } \\
\text { cecal landmarks) }\end{array}$ & $\begin{array}{l}\text { Cecum, appendicular orifice, and cecal strap fold } \\
\text { Cecum and ileocecal valve }\end{array}$ & $\begin{array}{l}\text { Rectum in } \\
\text { retroflexed view }\end{array}$ & - \\
\hline Tang et al. [9] (2015) & $\begin{array}{l}\text { Optional } \\
\text { (if intubated) }\end{array}$ & $\begin{array}{l}\text { Cecum, appendiceal orifice, and ileocecal valve } \\
\text { Ascending colon } \\
\text { Transverse colon } \\
\text { Descending colon } \\
\text { Sigmoid colon }\end{array}$ & $\begin{array}{l}\text { Rectum in both } \\
\text { forward and } \\
\text { retroflexed views }\end{array}$ & $\begin{array}{l}\text { Optional (if they are } \\
\text { relevant to the } \\
\text { presenting symptoms) }\end{array}$ \\
\hline
\end{tabular}

* In cases in which procedures are aborted because of poor preparation or severe colitis, photo documentation should be provided to support the decision to abort the examination.

Image Documentation in Gastrointestinal Endoscopy
GE Port J Gastroenterol 2017;24:269-274 DOI: $10.1159 / 000477739$ 
important anatomic landmarks is suggested despite no specific landmarks are proposed. In colonoscopy, the ASGE recommends 2 images of cecal landmarks (one including the appendiceal orifice and ileocecal strap, and the other including the ileocecal valve) and 1 more image of the rectum (in retroflexed view).

Recently, in 2015, Tang et al. [9] published a relevant paper on endoscopic image documentation. The authors

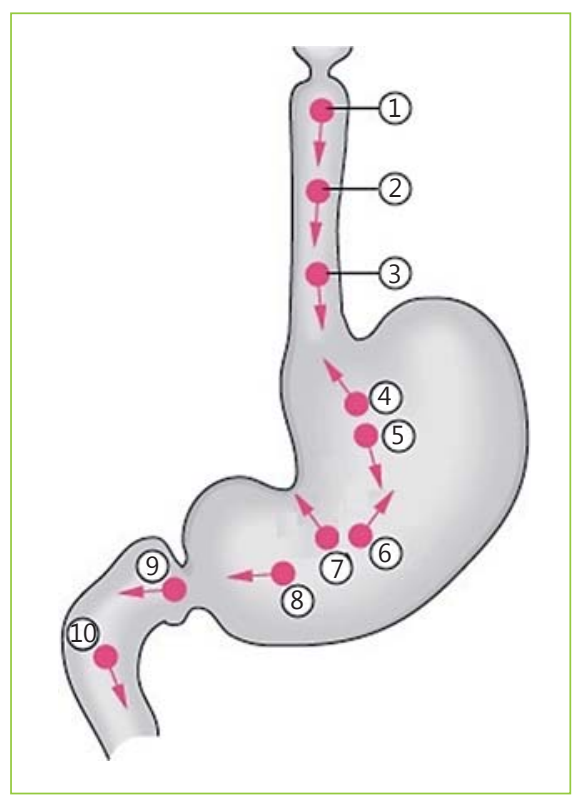

Fig. 1. Suggested systematic imaging in upper GI endoscopy (adapted from the ESGE [1]). not only highlight the role of photo documentation in GI endoscopy but also indicate a specific set of landmarks for upper and lower GI endoscopy.

\section{Principles and Techniques}

In both upper and lower GI endoscopy the role of systematic endoscopic image documentation is to:

1 show crucial anatomic landmarks;

2 document the extent of the examination; and

3 reflect the quality of cleansing and mucosal visualization.

According to most recent ESGE recommendations on imaging in upper and lower GI endoscopy, published in 2016 and 2012, respectively, we propose a set of images to be routinely captured. In upper GI endoscopy, a total of 10 images of specific landmarks should be captured (Fig. 1, 2a-j):

1 - Proximal esophagus;

2 - Distal esophagus;

3 - Z-line and diaphragm indentation;

4 - Cardia and fundus on retroflexed view;

5 - Body (including lesser curvature);

6 - Body on retroflexed view;

7 - Angulus on partial retroflexion;

8 - Antrum;

9 - Duodenal bulb;

10 - Second part of the duodenum, including the ampulla.

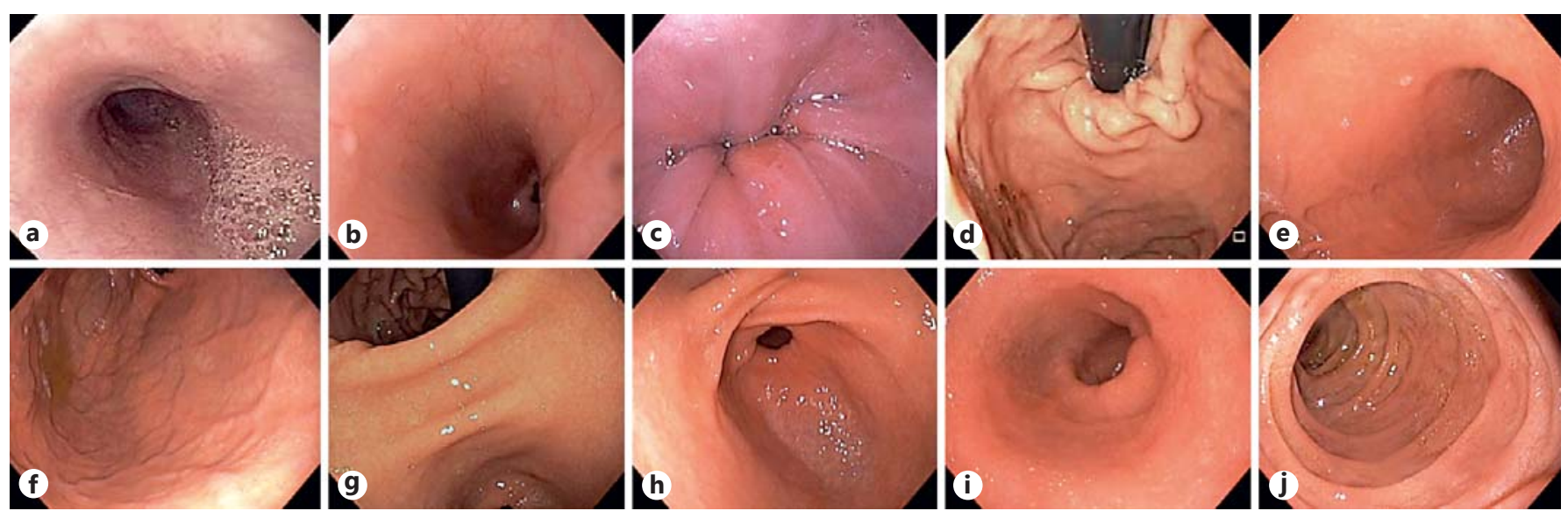

Fig. 2. Examples of systematic imaging in upper GI endoscopy. a Proximal esophagus; b distal esophagus; c Zline and diaphragm indentation; $\mathbf{d}$ cardia and fundus on retroflexed view; e body (including lesser curvature); $\mathbf{f}$ body on retroflexed view; $\mathbf{g}$ angulus on partial retroflexion; $\mathbf{h}$ antrum; i duodenal bulb; $\mathbf{j}$ second part of the duodenum, including the ampulla. 
In colonoscopy, 9 photographs should be systematically taken (Fig. 3, 4a-i):

1 - Lower part of the rectum in retroflexed view;

2 - Lower part of the rectum (taken $2 \mathrm{~cm}$ above the anal line);

3 - Middle part of the sigmoid;

4 - Descending colon just distal to the splenic flexure;

5 - Transverse colon just proximal to the splenic flexure;

6 - Transverse colon just distal to the hepatic flexure;

7 - Ascending colon just proximal to the hepatic flexure;

8 - Cecum and ileocecal valve;

9 - Cecum and appendiceal orifice.

In addition to photo documentation of the normal endoscopic features, image acquisition of pathologic findings is mandatory as it complements report description. It should show the lesion(s) (if focal) or a representative area of diffuse pathology for localization and characterization and for potential follow-up and/or therapy. Moreover, endoscopic therapeutic procedures should also be recorded. Imaging before, during, and at the end of the procedure, as well as of any relevant procedural complication is recommended (Fig. 5).

Video documentation of endoscopic procedures is becoming increasingly available. In certain situations, video may be superior to photo documentation, e.g., when showing a therapeutic procedure. At the present time, full video documentation of all endoscopic examination is not advocated by either the ESGE or ASGE.

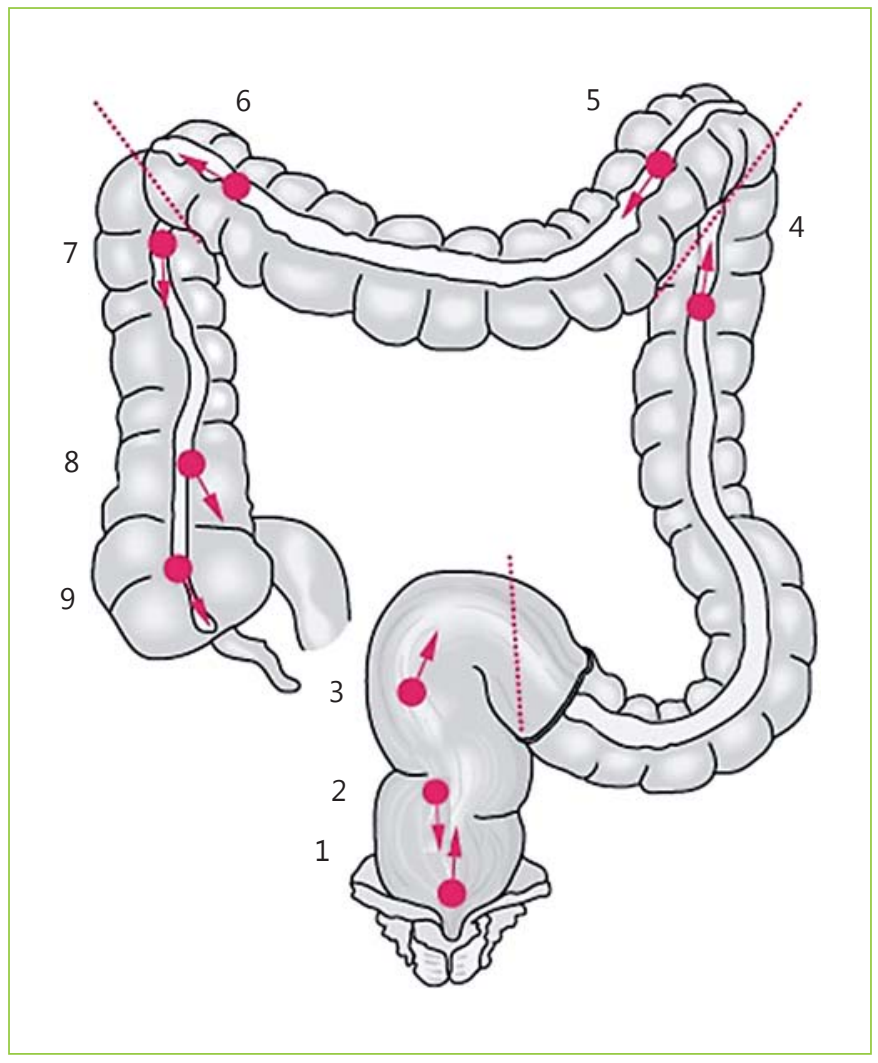

Fig. 3. Suggested systematic imaging in colonoscopy (adapted from the ESGE [1]).

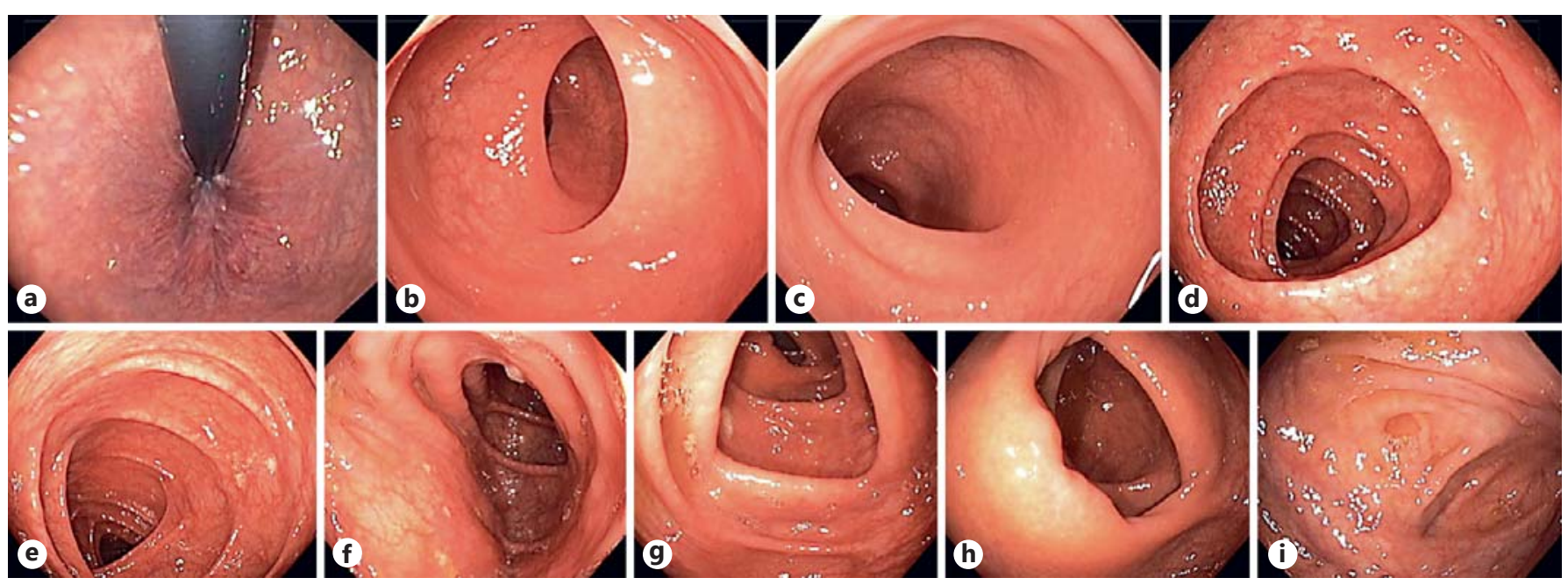

Fig. 4. Examples of systematic imaging in colonoscopy. a Lower part of the rectum in retroflexed view; $\mathbf{b}$ lower part of the rectum (taken $2 \mathrm{~cm}$ above the anal line); $\mathbf{c}$ middle part of the sigmoid; $\mathbf{d}$ descending colon just distal to the splenic flexure; e transverse colon just proximal the splenic flexure; $\mathbf{f}$ transverse colon just distal to the hepatic flexure; $\mathbf{g}$ ascending colon just proximal the hepatic flexure; $\mathbf{h}$ cecum and ileocecal valve; $\mathbf{i}$ cecum and appendiceal orifice.

Image Documentation in Gastrointestinal Endoscopy
GE Port J Gastroenterol 2017;24:269-274 DOI: $10.1159 / 000477739$ 
Fig. 5. Examples of systematic imaging in endoscopic therapeutic procedures - mucosectomy. a Before the procedure, $\mathbf{b}$ during the procedure, and $\mathbf{c}$ after the procedure.
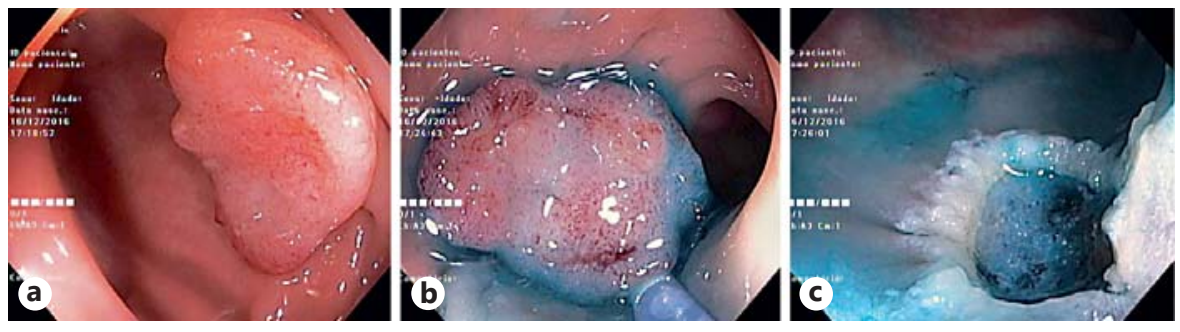

For both photo and video documentation, the best quality imaging requires a clear lens, optimized focus and light, sufficient luminal distension, and optimal cleansing of the area of interest.

\section{Conclusion}

Accurate and adequate image documentation is an essential part of GI endoscopic reporting. At the present time, systematic photo documentation is recommended by major endoscopic societies, including the ESGE and ASGE, and has become an integral aspect of quality control. Therefore, systematic imaging should be routinely performed in upper and lower GI endoscopy, and infor-

\section{Statement of Ethics}

This study did not require informed consent or review/approval by the appropriate ethics committee.

\section{Disclosure Statement}

All authors have nothing to disclose.

\section{Author Contribution}

S.M. wrote the manuscript. M.B., P.P.-N., C.C., and M.D.-R. were responsible for the revision of its contents. mation systems should incorporate this relevant data.

\section{References}

1 Rey JF, Lambert R, et al: ESGE recommendations for quality control in gastrointestinal endoscopy: guidelines for image documentation in upper and lower GI endoscopy. Endoscopy 2001;33:901-903.

2 American Medical Association and National Committee for Quality Assurance: Endoscopy and polyp surveillance - physician performance measurement set. http://www.ama-assn.org/ama1/pub/upload/mm/370/endoscopy-ms.pdf.

3 Rembacken B, Hassan C, Riemann JF, Chilton A, Rutter M, Dumonceau JM, et al: Qual- ity in screening colonoscopy: position statement of the ESGE. Endoscopy 2012;44:957968.

4 Bisschops R, Areia M, Coron E, Dobru D, Kaskas B, Kuvaev R, et al: Performance measures for upper gastrointestinal endoscopy: a European Society of Gastrointestinal Endoscopy (ESGE) quality improvement initiative. Endoscopy 2016;48:843-864.

5 Aabakken L, Barkun AN, Cotton PB, Fedorov E, Fujino MA, Ivanova E, et al: Standardized endoscopic reporting. J Gastroenterol Hepatol 2014;29:234-240.
6 ASGE/ACG Task Force on Quality in Endoscopy: Quality indicators for GI endoscopic procedures. Gastrointest Endosc 2015;81:1-80.

7 Park WG, Shaheen NJ, Cohen J, Pike IM, Adler DG, Inadomi JM, et al: Quality indicators for EGD. Gastrointest Endosc 2015;81:17-30.

8 Rex DK, Schoenfeld PS, Cohen J, Pike IM, Adler DG, Fennerty MB: Quality indicators for colonoscopy. Gastrointest Endosc 2015; 81:31-53.

9 Tang SJ, Raju G: Endoscopic photography and image documentation. Gastrointest Endosc 2015;82:925-931. 